\title{
Should Development Studies Be Taught in Britain?
}

\section{John Oxenham}

The question of the title provoked in me a response so strongly affirmative, that it seemed astonishing it was posed at all. Since all the institutions represented at the conference which was the origin of this Bulletin actually do teach development studies in Britain, probably this reaction was not unique, although, to be sure, many of us may have been pricked by doubt from time to time. But perhaps our reactions need to be examined. What is the point of departure?

I take it as an axiom (in the sense of a principle of intrinsic merit and not in the sense of a self-evident proposition), that I have a duty to love my neighbours, which requires me at the least to wish their good. If I want or feel obliged to come under pressure to go beyond that minimum and actually do something to promote their good, then, again at the least, I have a duty to ascertain what their good actually is. That duty predicates a right to investigate the matter, do some research on it, in order to avoid mistaking it. For simple instance, if a neighbour is in a poverty trap and $I$ wish to participate in his liberation, I must at least ascertain how the trap can be sprung without damaging him further. The absurdities of ignorant charity have long been the butt of academic and cynics alike.

The right to investigate is reinforced from a second source, namely natural curiosity. In recent centuries, indeed, the cultivation of this has become more and more firmly enshrined as a function of enlightened education. Its pursuit has attracted incalculable investment. Curiosity is the engine by which we have reached the outer planets. At the same time, nowhere does it flourish more vigorously than in knowing about our neighbour's business-and interfering with it. We need discipline to keep out of each others' affairs. Whether curiosity and meddlesomeness predicate a universal human right to information, investigation and reflection is doubtful in logic, but irresistible in practice. The very elegance of Pope's apothegm, 'the proper study of mankind is man' underscores how hard we work to legitimise that from which we cannot desist.

I assume development studies to be about people and about their well-being. Clearly, I also assume that the idea of neighbour encompasses a great many more folk than the family next door and invades all sorts of boundaries, political, cultural, linguistic and racial. Further, I attempt partially to. legitimise curiosity by bracketing it with love and, in doing so, give development studies a moral colouring.

Yet the two are obviously separable. While the wise practice of love may require the exercise of some restricted curiosity, the practice of curiosity does not require the motive of love. The recent recrudescence of concern for participatory research and denunciations of academic imperialism suggest that it is only too easy for curiosity to displace love. In development studies, then, as in other fields of enquiry, love of one's neighbour is not of the essence of the art-even though it may be the initial motive propelling a particular individual into the field. Whether the separation of the two, the adoption of a 'purely' academic stance, promises good, evil or irrelevance to sound development studies, is an issue which will not be pursued further here.

Even if we accept that curiosity about other human beings is a human drive which must be allowed legitimate range, we can discuss what limits might need to be set upon it. I have exposed my own assumptions that the world is my neighbour and, within whatever bounds of propriety are drawn, I have a right to study the entire human race; where and how I study my fellows is essentially my choice-even though I may be blocked by the choices of those whom I want to study or by their representatives.

It follows that, if I teach what I study, the place of teaching is also essentially my choice. The question of this article challenges those views. It seems to imply that there may be something about development studies which sets a country like Britain outside the bounds of propriety as a place for teaching. If a country like Britain is debarred, so too presumably are people like the British. If they are to be deterred from teaching development studies, would it not follow that they should not study development either? Would it not follow even more strongly that they should refrain from all forms of development activity, whether as field-workers, advisers, international civil servants or dispensers of development aid? The question reverberates with Dudley Seers' call [1979] to the rich battalions of development to come home. 
Reciprocally, if people in a country like Britain do dare teach development studies, should people from countries which are not like Britain patronise the courses, or should they confine themselves either to their own countries or to countries like their own, for the purposes of development studies?

Questions such as these do not present themselves à propos subject like physics, literature, anthropology, or even Greek and Latin. Nobody suggests, so far as I am aware, that only the Italians should indulge in Latin, and that the British and Ghanaians should abandon it on principle. Nor is it contended that, for anthropological purposes, only the Bemba should study the Bemba or only Scots study Scots; still less that people should study the Bemba only if they happen to be in the Northern Province of Zambia. What is it about development studies that excites what appears to be a species of xenophobia? I suspect it is two factors: the hangover of a steadily dating concept of what development studies is about, coupled with the applied and prescriptive nature of much of development studies, ie its meddlesomeness.

Sooner or later one has to resort to definitions; let me indicate roughly what I now mean by development studies. They comprise systematic attempts to understand, on the one hand, how and why nation states and their subordinate social organisms attempt, succeed or fail in increasing the wealth, improving the well-being and widening the rights and opportunities available to their members; and, on the other, how nation states and other agents in international relationships-such as transnational corporations-help, obstruct or exploit each other in the said success and failure.

Such a formulation suggests a pure or academic form of development studies, which has no ambition beyond understanding. It suggests, too, that all nation states are treated with equal attention in both sections of the division. Both suggestions would probably have been missing from any attempt I might have made, say, 15 years ago. Then I would most likely have said that development studies were about developing developing countries. My emphasis would have been intensely practical or applied, the international dimension would have been lacking, there would have been no hint that the developed countries were in any way still developing, and there would instead have been a firm, if tacit, assumption that they were the major repositories of development wisdom. I suspect that the question of the title would be put by a person still operating on this older definition and taking no account of the evolution of development thinking.
Yet such a person might well argue that my repentant formulation unhappily does not fit still current facts, while the old one does. Most courses of development studies, he might allege, still focus and are expected to focus on implications for policy, planning, programmes and projects. They are justified less as education and more as training. While theory is acknowledged to be important, the emphasis is on application. Development studies is still very much a stamping ground for people concerned, and often paid, to promote their neighbours' good, not simply to think about it.

Second, the policy and programmes are in bulk not applicable equally to developed and less developed states, but refer mainly to the latter. The actual operating bias, if not principle, is that, whatever the role of the developed countries, development happens in the developing ones. Attention is indeed given to the impact of rich country policies upon the poor. Relatively little is given to the effects of the poor upon the rich, or even of the rich upon each other. Development studies, as taught today, are substantially a specialisation in the current internal development of the poorer states of the world.

Third, the hollowness of my updated definition is demonstrated by the very population of the courses on development studies. If these courses were equally concerned with developed and developing countries, the students on them would probably reflect the composition of the student body in Britain. On undergraduate courses, students from developing countries might account for some 10 per cent of the enrolment, while among postgraduates, they might make up perhaps a third. The figures provided to Deryke Belshaw turn that supposition upside down [IDS forthcoming 1980]. On the postgraduate courses listed in his paper, almost 90 per cent of the enrolment is drawn from developing countries. The upshot of the allegation is that actual courses on development studies have not caught up with development thinking. They still carry their historical legacy in orientation, focus and population. Even if this were true, would it indicate that such courses in Britain should be abolished?

Let me oppose myself and start on an answer with an obvious observation. It may well be that directors and teachers of development studies studiously eschew prescription, focusing instead intently on issues, options and techniques useful in assessing alternatives. Nevertheless, those who offer to teach or, even more modestly, to guide study must needs have some advantage over those who come to learn on courses. Those who teach development studies must have some comparative advantage in learning 
about development. In the current context of Britain's courses, the insinuation is that people from developing countries-plus a minority of others - can learn about their own conditions as effectively, possibly more effectively in Britain than in their own countries. The truth of this can be left for later discussion.

Wrapped up in that first insinuation is another. Since the courses are taught in the main by British lecturers, possibly with the assistance of a few tame refugees from developing countries, it must be supposed that the British have a comparative advantage in understanding developing societies. To be sure, the legacy of empire includes a number of people who did actually work in villages, run government machinery and design all manner of development programmes. And there are people who formed the steady flow of technical cooperators under a variety of bilateral and multilateral programmes, and other people who simply undertook their own research. Even so the stock of possible teachers of development studies does seem to be dwindling, and with it the comparative advantage. So development studies as practised heretofore should be shrinking and in the process of transforming its content and student body.

Yet, miraculously, the numbers of courses in development studies is on the increase. This paradox may be a manifestation of one of Parkinson's Laws. Equally, it may be the logical evolution of a vested interest. Because of the original advantage, some courses were set up. Because of the courses, more British people got themselves involved in developing countries and so more courses were generated. Consequently, even more British steep themselves in development and then purport to have acquired a comparative advantage. The self-perpetuation of a profession is under way.

The process would be unexceptionable-who worries after all that American scholars teach European history in America to American students?-but for the fact that development studies are not taught in the main to the students of developed countries. What this suggests is that courses in development studies in Britain are in direct and active competition with similar potential or actual courses in developing countries. This competitive-and obversely depressive-power is reinforced by the support they receive for their faculty and students from the British aid budget. On Belshaw's information, some 40 per cent of the students who are in development studies and from developing countries are financed by Britain. The unequal competition is skewed even more by other advantages, internal and external, enjoyed by institutions in rich countries. In short, there is a case for supposing that development studies, as currently taught in Britain, are underdeveloping development studies in developing countries themselves.

At the same time, they are using the developing countries to maintain their competitive advantage. Their faculty are encouraged to work from time to time in such states, so as to replenish their professional capital, as well as their operational funds. Second, many of the courses require their rich country students to have had experience of work in development-but not development in rich countries. In other words, the developing countries are expected to permit tyros to thrash about among their problems, possibly with some benefit to themselves-most go on permitting it--but certainly with benefit to both the numerical force of the professional cadre and to its range of expertise.

A further snide observation can be made in parenthesis about the minorities of rich country students. Some of them enter the pool from which the agencies of international aid recruit their permanent professional cadres. Since the posts available have to be distributed among the member nationalities on bases other than the degree to which they require aid, the rich countries can consolidate their position by claiming to have properly qualified people on offer. On the other hand, it is an easy riposte that as the rich countries would keep their shares anyway, better that their candidates should be more rather than less qualified.

Taken together, these three points indicate a classic charge of exploitation: giving a sop in return not just for large profit but actually for stunting him who accepts the sop. How just is such a view? I find myself reluctant to credit that any competition there may be is deliberate or concerted. On the contrary, getting resources for courses in development studies seems to have been arduous and uncertain. From an historical perspective, the hypothesis of filling a vacuum strikes me as more plausible. Although training courses of many kinds have existed since 1945, courses in development studies as such are almost a phenomenon of the 1970s. Also they tend to be a phenomenon of the richer countries. Which prompts a paraphrase of Holtham's and Hazlewood's remarks on educational aid to Kenya: would a lack of initiative in Britain have meant more and better development studies in developing countries, or even less and worse? [Holtham and Hazlewood 1976: 253] 
An answer to the question may be implicit in another part of Belshaw's information [IDS forthcoming 1980: table VI A and B]. True, 40 per cent of students are paid for from British aid. Also true is that a further 35 per cent are paid for by the governments of developing countries out of their own resources. The residual 25 per cent are financed out of 'private or other' sources.' The implications of these facts may be two. One, governments and individuals do not know of, or have not located, plausible alternative centres for development studies-so that technical cooperation between developing countries is not yet a fully fledged option. Second, the quality and relevance of development studies in Britain have so far been worth paying for, even out of stretched development budgets. The British initiative then seems to have justified itself and the world might have been a worse place without it.

As for the sop: while it cannot be denied that many technical cooperators and researchers do leave little benefit and sometimes much distaste with their hosts, the balance of benefit must be sufficent at least to maintain the inertial momentum of technical cooperation. Were there only suffering attached, even the most pliant government would have surely called a halt.

But my devil can open another ground of attack. Even if Britain and other rich countries were not competing with and stifling development studies in developing countries, even if perpetuating the development studies profession in Britain did not involve exploitation, is it not still the case that British teachers of development studies are inconsistent within their own terms? Their courses are advertised as primarily applied, they express preferences for students who are practitioners and those experienced in development, and they focus on situations within developing countries. Yet they conduct their courses in places quite divorced from the situations of their concern. Elementary theories of learning would suggest that they have thereby denied themselves valuable, even essential, means of ensuring the comprehension of what is taught and its assimilation inte behaviour and practice. Indeed, they are promoting useless learning, in that much of what is learned only from lectures, books, classroom exercises and term papers will be forgotten, precisely because it will not have been mobilised within a real situation. If not forgotten, it may simply persist in parallel with unchanged practice. In effect, British and similar teachers of development studies deny

\footnotetext{
1 In other areas of study in Britain, 75 per cent of overseas students are financed from 'private or other' sources. A possible inference is that development studies have not yet established themselves as a credential for a lucrative profession.
}

their students the full potential benefit of what they purport to be offering. More snidely, by opening vistas and shutting off continuing contact with reality, they may even be deepening a sense of inadequacy in their students and hence perpetuating a dependence on the profession of development studies.

The teachers may counter by arguing either that their students use their remembrances of things past as satisfactory surrogates for immediate dialectic with reality; or that it is the responsibility of the students to adapt what has been learned to particular circumstances, when they get home. Such defence is disingenuous on two grounds. First, things past have not been systematically noted: what remains in the memory is not comprehensive, reliable or even fixed. To base academic study on it is insidiously to devalue the study, simply by making it academic in their sense of unreal. Second, when the students get back to their jobs, they are pressed by the present, have much less opportunity for reflection and no opportunity at all for tutorials. That is, the likelihood of their being able to incorporate a substantial proportion of their learning into their practice is severely curtailed. It would follow that much of their time is virtually wasted by what could be construed as almost false pretences.

My devil seems to imply that, if courses of development studies cannot be conducted perfectly, they ought not to be conducted at all, or more generally, when faced by two evils, the correct choice is paralysis. I would reject that. Further, I would assert that the imperfections of courses run in real, live developing countries would be only a little less than those of Britain's, if indeed they were less. In any situation of instruction, compromises have to be made between prescriptions derived from theory and constraints imposed by circumstances. The issue, then, is which circumstances impose the least harmful compromises. There is no evidence, so far as I know, that the British compromises are either totally harmful or so devoid of benefit that their costs cannot be justified. If there could be confidence that, given the extinction of courses of development studies as presently practised in developed countries, more numerous and more relevant replacements would arise in developing countries, the compromises in Britain might be discarded. Failing that, I would plump for half a loaf of bread.

Finally, what of the problem of cultural dependence? Institutions of development studies are not independent of their social and ideological matrices. British courses in the area are bound then to be biased towards rich country perspectives on 
development processes. Will they not tutor their students to adopt their views? Might this not lead, as it has in areas like architecture, to inappropriate-even harmful-proposals and policies? In response, I am driven to ask whether the students selected for development studies are uniformly docile morons, incapable of independent assessment. And whether their tutors are monolithic, unswerving indoctrinators. People are indeed influenced by each other: that is part of the human condition. But people also react against each other. What makes for imitation and what for rebellion? Somewhere those who teach have to put their trust in the intelligence, good sense and autonomy of at least some of their students. Otherwise we desist not only from courses in development studies, but from all courses.

\section{References}

IDS, forthcoming 1980, Courses on Development at Graduate Level in Britain, IDS, Sussex (see Editorial for details)

Seers, Dudley, 1979, 'The birth, life and death of development economics: revisiting a Manchester conference', in a special issue in honour of Kurt Martin, Development and Change, vol 10, pp 707-19. Also available as an IDS Reprint, IDS Sussex. 